\title{
INFLUENCE OF SELECTED FACTORS ON ERODIBILITY IN CATCHMENT SCALE ON THE BASIS OF FIELD INVESTIGATION
}

\author{
Leszek Hejduk' ${ }^{1}$ Agnieszka Hejduk², Anna Baryła ${ }^{3}$, Edyta Hewelke² \\ 1 Department of Hydraulic Engineering, Warsaw University of Life Sciences - SGGW, Nowoursynowska 159, \\ 02-776 Warsaw, Poland, e-mail: leszek_hejduk@sggw.pl \\ ${ }^{2}$ Laboratory-Water Center, Warsaw University of Life Sciences - SGGW, Nowoursynowska 159, 02-776 Warsaw, \\ Poland, e-mail: agnieszka_hejduk@sggw.pl \\ ${ }^{3}$ Department of Environmental Improvement, Warsaw University of Life Sciences - SGGW, Nowoursynowska \\ 159, 02-776 Warsaw, Poland
}

Received: 2016.10.15

Accepted: 2016.11.16

Published: 2017.01.01

\begin{abstract}
Drying of soil surface can affect the soil water repellency and reduce the infiltration, it may have impact on runoff and erosion. The aim of the research was to determine the effect of soil surface drying on its repellency and erosion, and the dependence of these values from the land use on the changing weather conditions background during the year. The research was conducted on Zagożdżonka river catchment, six times during the period of July 2014-September 2015, at five measuring points characterized by different land use. The irrigation of soil was carried out using rainfall simulator made by Eijkelkamp company. The intensity of the rain during the first 3 minutes of precipitation was $6 \mathrm{~mm} / \mathrm{min}$, the kinetic energy of rain was $72 \mathrm{~J} \cdot \mathrm{m}^{-2}$. The surface runoff was collected into containers placed in the bottom of the rainfall simulator. Water Drop Penetration Time test was used to determine soil surface wettability. WET-2 probe was used to measure the moisture and soil temperature. Sediment concentration in the effluent was determined by weight method on filters. Variability of soil wettability was observed in different dates of measurements. Increasing repellency was recorded during the dry periods. The highest class of repellency was found in the forest and wild meadow areas. There was no direct correlation between the soil moisture, soil temperature and runoff. Both, sediment concentrations and sediment grain size, varied in the collected samples, depending on measurement time. The highest sediment concentrations were found in runoff from agricultural land use.
\end{abstract}

Keywords: erodibility, catchment scale, rainfall simulation

\section{INTRODUCTION}

Due to the transformations in agriculture at the Mazovian lowlands, soils with low productivity, such as sandy soils become slowly abandoned. On the one hand, it might be the consequence of the migration of population from rural areas into cites, and from small cites (subregional centers) into bigger, regional centres [Bański, Czapiewski 2015]. On the other hand, strong fragmentation of farms, where $79 \%$ of farms are smaller than 10ha [Sulmicka 2013] is also a significant fac- tor. This fragmentation and relatively small-sized farms with sandy soils do not generate enough income from agriculture. From the land protection point of view, the reduction of agricultural land and increasing forest areas can help dealing with threats connected with climate change [Starkel, Kundzewicz 2008].

High antecedent soil moisture can indicate risk of surface runoff in agricultural watersheds and can also influence the quantity of surface runoff generated during rainfall events [Radatz et al. 2012]. Defersha et al. [2011] found that the rate 
of interrill erosion varied significantly with antecedent moisture content; sediment yield from wet soils was $50 \%$ lesser than from air-dried soils.

Water relations are one of the most variable characteristics of the soil environment. The simplest indicator showing water conditions of the soil is the moisture content [Somorowski, 1998]. Many authors [Le Bissonais et al. 1995; Römkens et al. 2001; Żmuda et al., 2007] drew attention to the importance of the initial moisture content of the soil to the diversification of erosion. Initial moisture is one of the main factors influencing the infiltration process. Monitoring changes in soil moisture allows to create databases, which together with other features of the soil environment can be later used for forecasting the risks of erosion [Rose et al., 1983; Laflen et al., 1991; Misra et al., 1996; Schmitz 1997; Deletic 2001; Yu 2002, Ries et al. 2009]. Research conducted by Brodowski [2009] indicated that soil moisture at the start of precipitation and the state density have a significant influence on the formation of both the process of erosion and absorption of rainwater. Higher humidity initial subsurface soil layer leads to a faster increase in surface runoff and may be associated with runoff stabilization on a bigger scale. Under the influence of rainfall, soil aggregates of higher humidity are destroyed rapidly, and the resulting shell surface significantly reduces infiltration and contributes to increase the amount of surface runoff and transferred soil. This means that the extreme (very high or very low) initial moist soil and detached crusting surface of eroded soil material can be moved over a longer distance. Wei et al. [2007] found two different functions of antecedent soil water potential to runoff coefficient during the wet and dry periods.
Evaluation of the severity of erosion involving the analysis of the transport of soil material in watercourses does not allow for a full assessment of water erosion within the same catchment area, especially in the short rafting or where surface water is not discharged beyond the catchment area [Rejman, Usowicz 1999]. Therefore, it was advisable to carry out tests on a small scale, thus determining the number of surface run-off and erosion, assuming variable initial conditions such as start humidity, temperature and soil use.

The investigation carried out in Zagożdzonka river catchment between July 2014 and September 2015 included the rainfall simulator experiment, which together with the information on precipitation, temperature and soil moisture at various sandy soils type and land cover, should give the general overview of differences in erosion processes within a small lowland catchment. This work differs from previous studies in two respects: firstly, it was made under rather dry conditions comparing five different environments on sandy soils; secondly, it places emphasis on antecedent conditions rather than on infiltration itself.

\section{MATERIAL AND METHODS}

Field investigation of Zagożdżonka catchment for hydrological purpose was started by the present Department of Hydraulic Engineering of Warsaw University of Life Science in 1962 at Płachty Stare gauge. About 20 years later, monitoring of the river flow at Czarna gauge has begun. Since 1991, the investigation has been intensified and the river gauging station at Czarna has been equipped with automatic recorders of

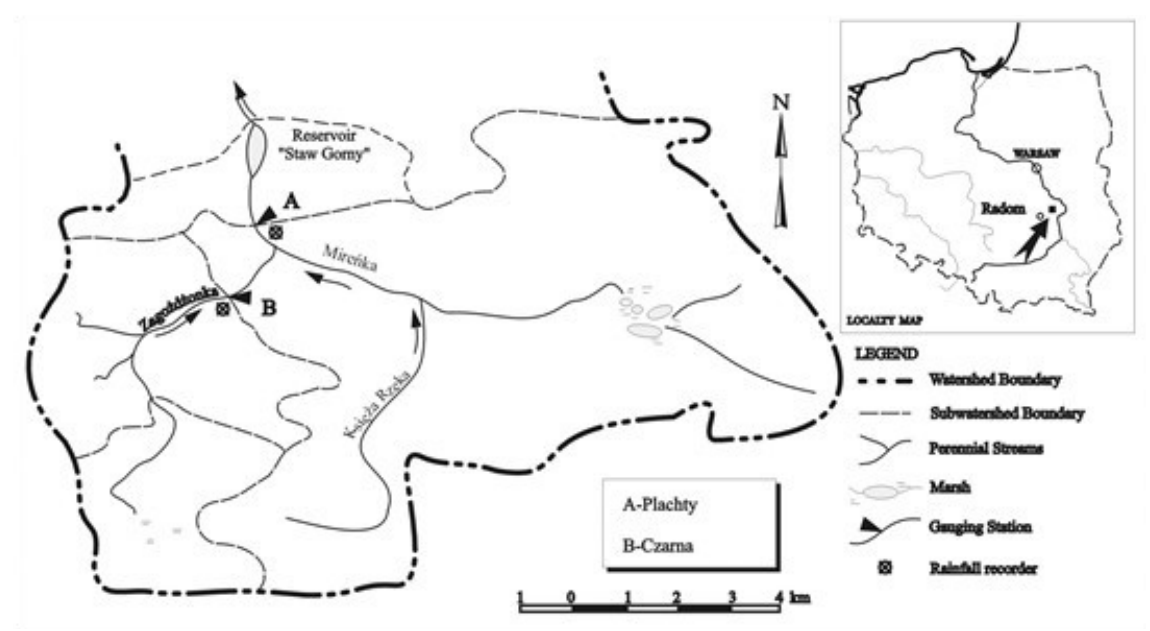

Figure 1. Location of Zagożdzonka river catchment 
rainfall, water level and with devices measuring water quality parameters, i.e. temperature, turbidity and sediment transport. Later on, an electronic system of data recording, logging and transmitting was installed. Zagożdżonka catchment, shown in Figure 1 is located in central Poland, about 100 $\mathrm{km}$ south of Warsaw. The catchment area at Czarna is $23.4 \mathrm{~km}^{2}$ and at Płachty Stare $84.2 \mathrm{~km}^{2}$.

The mean annual precipitation and runoff are estimated at 610 and $106 \mathrm{~mm}$ respectively (Fig. 2), based on 50-years (1963-2012) [Banasik et.al. 2013] data records collected by the Department of Hydraulic Engineering of Warsaw University of Life Sciences at Płachty Stare, except for precipitation data for the period 1963-82. This period of data was taken from available publications of Polish hydro-meteorological service IMiGW for the nearest rain gauge Zwolen. The maximum precipitation of $941 \mathrm{~mm}$ was recorded in 1974 and the minimum of 414 in 1991 [Banasik et al. 2013]

Maximum annual runoff of $209 \mathrm{~mm}$ was measured in 1980 and the minimum of $52 \mathrm{~mm}$ in 1992. The precipitation during the period of DecemberFebruary, is c. $103 \mathrm{~mm}$, i.e. $16.9 \%$ of the total annual amount, mainly in the form of snow [Banasik et al., 2014]. The topography of Zagozdżonka catchment is typical for lowlands in Central Poland. Absolute relief is $26.5 \mathrm{~m}$, the mean slopes of main streams are from 2.5 to $3.5 \mathrm{~m}$ per 1000 $\mathrm{m}$. Local depressions, which do not contribute to direct runoff and sediment yield from the catchment, constitute a significant part of the $3.8 \mathrm{~km}^{2}$ area upstream of Czarna. Land use is dominated by arable land (small grains and potatoes), which occupies about $70 \%$. About $20 \%$ of area is covered by forests and about $10 \%$ are pastures (Banasik, 1994). Sandy soils are the dominant type in the watershed area (light loamy sand $-40.2 \%$; loamy sand $-50.5 \%$ and organic soils $-9.3 \%$ )

\section{Description of the experimental plots and rainfall experiment setup}

On the basis of the identified soils types and land cover, the 5 plots were assumed as representative ones in the catchment and have been chosen for rainfall simulation experiments. The basic information about plots locations, as well as soils characteristics and land cover are shown in Table 1.

The rainfall experiment was conducted using a rainfall simulator made by Eijkelkamp (Fig. 3), with stable rainfall depth and intensity. Some authors [Cedra and Doerr 2007, Iserlohn et al. 2013; Ries et al. 2013] drew attention to the significance of repeatability of the same conditions of precipitation for each location, as well as repeatability of the spatial distribution and droplet size distribution of precipitation. This premise was adopted in the presented investigation.

The maximum rainfall volume for one rainfall simulation is limited by the device [Eijkelkamp 2005] and its design, to secure the rainfall intensity of $350 \mathrm{ml} / 1$ minute. On the basis of historical precipitation data at Czarna meteorological gauge, the maximum 10 minutes intensity recorded during 2010-2015 does not exceeded 9.9 $\mathrm{mm} / 10$ minutes. The USLE [Wischmeier, Smith 1978] rainfall erosivity factor assumes that the rainfall causes erosion if the total rainfall depth is over $12.7 \mathrm{~mm}$, and in case of lower rainfall, if the maximum rainfall intensity is greater than 6.3 $\mathrm{mm} / 15 \mathrm{~min}$ [Banasik 1994]. On the basis of this information, and taking into account the limitation of the rainfall simulator, the designed rainfall intensity for all experiments has been established as $6 \mathrm{~mm} / 8$ minute. Samples of overland flow were collected per each simulation to determine the sediment concentrations and sediment yield.

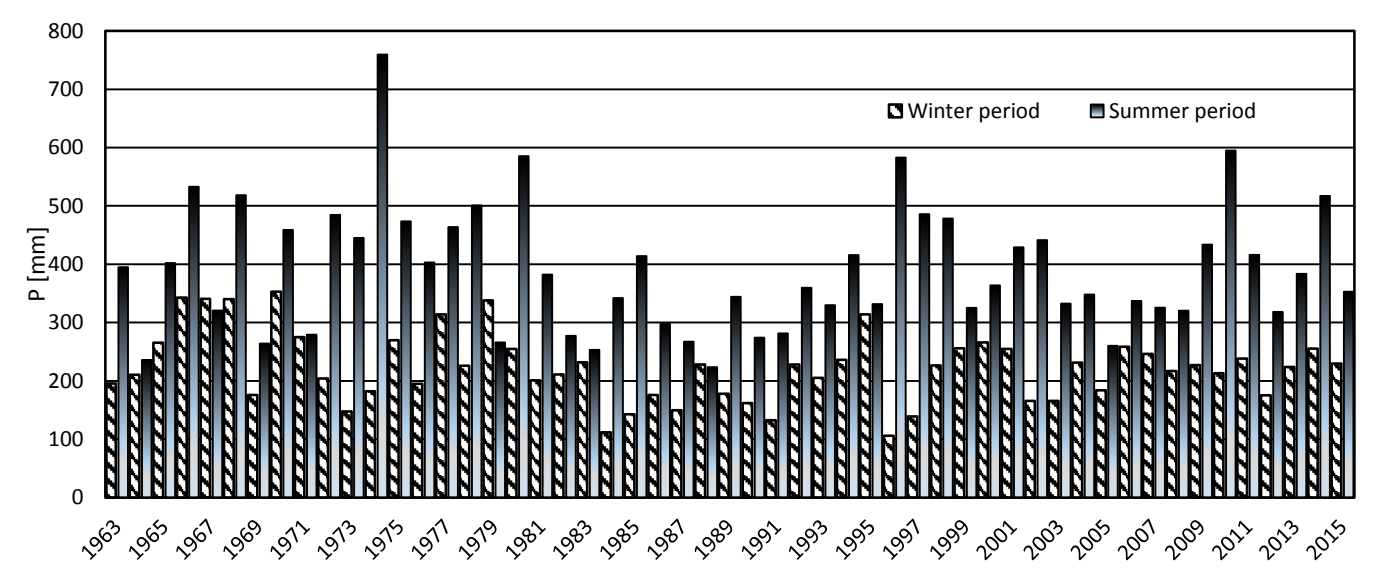

Figure 2. Long time yearly precipitation for winter and summer periods for year 1963-2015 
Table 1. Basic information about soils at particular experimental plot.

\begin{tabular}{|c|c|c|c|c|c|c|c|c|}
\hline \multirow{2}{*}{ Plot } & \multirow{2}{*}{$\begin{array}{l}\text { Location } \\
\text { (name of the place) }\end{array}$} & \multirow{2}{*}{ Coordinates } & \multirow{2}{*}{ Land cover } & \multirow{2}{*}{$\begin{array}{c}\text { Soil type } \\
\text { (according to } \\
\text { WBR 2014) }\end{array}$} & \multirow{2}{*}{$\begin{array}{c}\text { Soil } \\
\text { texture } \\
\text { (UDSA } \\
\text { classifica- } \\
\text { tion) }\end{array}$} & \multicolumn{3}{|c|}{ Characteristic diameters } \\
\hline & & & & & & D10 & D50 & D90 \\
\hline 1 & Płachty & $\begin{array}{l}51^{0} 266^{\prime} 44^{\prime \prime} \mathrm{N} \\
21^{0} 27^{\prime} 40^{\prime \prime} \mathrm{E}\end{array}$ & $\begin{array}{l}\text { wild } \\
\text { meadow }\end{array}$ & Albic Podzols & Fine sand & 0.07 & 0.48 & 0.65 \\
\hline 2 & Kościuszków & $\begin{array}{l}51^{0} 26^{\prime} 08^{\prime \prime} \mathrm{N} \\
21^{0} 25^{\prime} 54^{\prime \prime} \mathrm{E}\end{array}$ & $\begin{array}{l}\text { arable land } \\
\text { (rye) }\end{array}$ & Albic Podzols & Fine sand & 0.05 & 0.35 & 0.55 \\
\hline 3 & Czarna & $\begin{array}{l}51^{0} 25^{\prime} 52^{\prime \prime} \mathrm{N} \\
21^{0} 26^{\prime} 59^{\prime \prime} \mathrm{E}\end{array}$ & $\begin{array}{l}\text { cultivatd } \\
\text { meadow }\end{array}$ & Albic Podzols & $\begin{array}{l}\text { Loamy } \\
\text { fine sand }\end{array}$ & 0.02 & 0.28 & 0.40 \\
\hline 4 & Cudnów & $\begin{array}{l}51^{0} 24^{\prime} 57^{\prime \prime} \mathrm{N} \\
21^{0} 25^{\prime} 05^{\prime \prime} \mathrm{E}\end{array}$ & $\begin{array}{l}\text { wild } \\
\text { meadow } \\
\text { with forest } \\
\text { succession }\end{array}$ & Albic Podzols & Fine sand & 0.05 & 0.36 & 0.55 \\
\hline 5 & Bieliny & $\begin{array}{l}51^{0} 25^{\prime} 21^{\prime \prime} \mathrm{N} \\
21^{0} 28 \text { '32”E }\end{array}$ & $\begin{array}{l}\text { about } 10 \\
\text { years forest }\end{array}$ & Albic Podzols & Fine sand & 0.05 & 0.37 & 0.55 \\
\hline
\end{tabular}

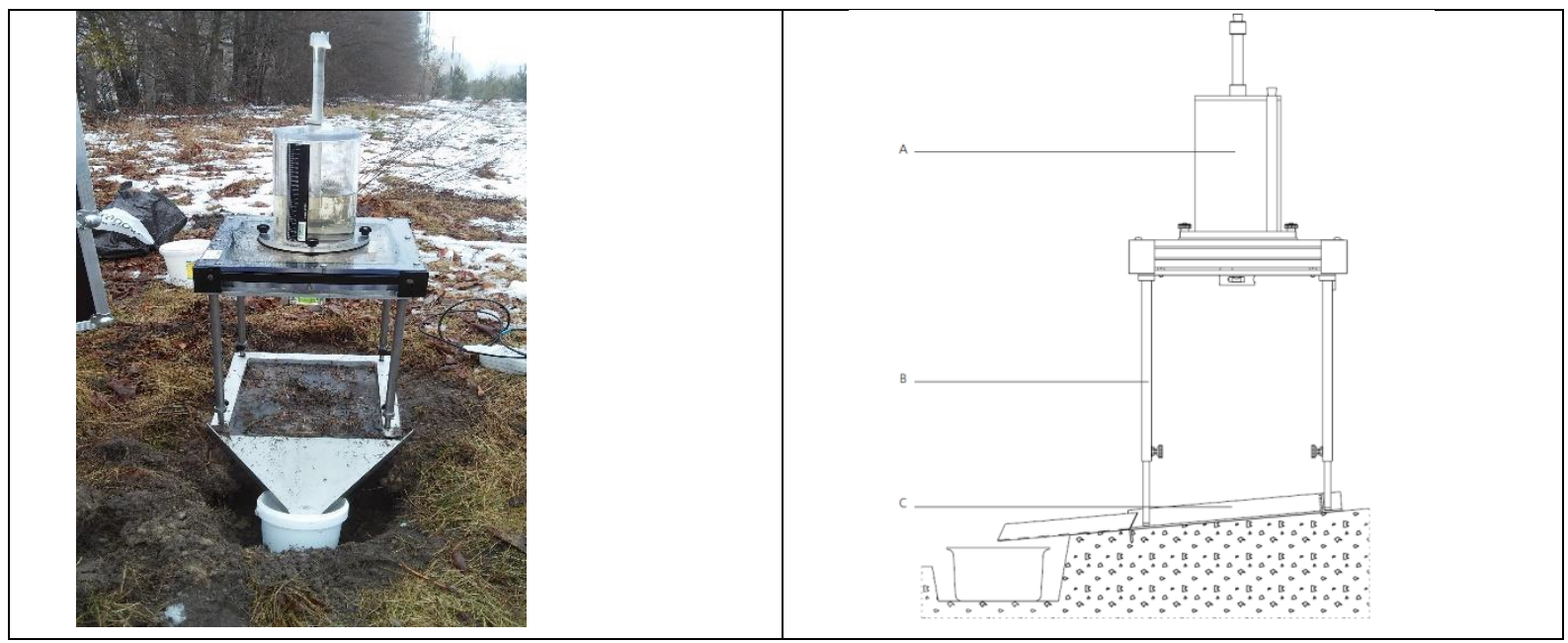

Figure 3. Rainfall experiment during snowmelt period (Fot. L.Hejduk) and scheme of the rainfall simulator [Eijkelkamp 2005]; A - sprinkler, B - adjustable support, C - ground frame.

Soil initial moisture content and temperature was measured by WET 2 probe. The soil surface repellency was determined in situ using the WDPT test prior to every simulation. WDPT test is the most widespread method for quantifying the persistence of soil water repellency (SWR) (Wallis \& Horne, 1992). Seven drops of distilled water, the volume of which is equal to $58 \mu 1$ each, were applied onto a representative soil surface and measuring the actual time until complete infiltration of each drop. The classification proposed by Dekker \& Ritsema (1994) was used in order to determine the five SWR classes. WDPT values of $5 \mathrm{~s}$ were taken as indicative of wettable soil conditions, 5-60 s as slight, 60-600 s as strong, 600-3600 s as severe and $>3600 \mathrm{~s}$ as extremely repellent.

\section{RESULTS AND DISCUSSION}

\section{Rainfall between experiments as indicators of soil moisture}

The experiment was conducted during hydrological years 2014 and 2015, starting from July 2014, with non-regular time step. The specific data of particular experiments were basically chosen on general metrological condition (temperature changeability and precipitation). The reason for that was to secure possibly the highest spatial and temporal variability of those conditions. Based on the sum of daily precipitation between particular experiments (Fig. 4), the second experiment has been performed after the wettest period during measuring period. On the other hand, the sixth experiment has been performed after the 


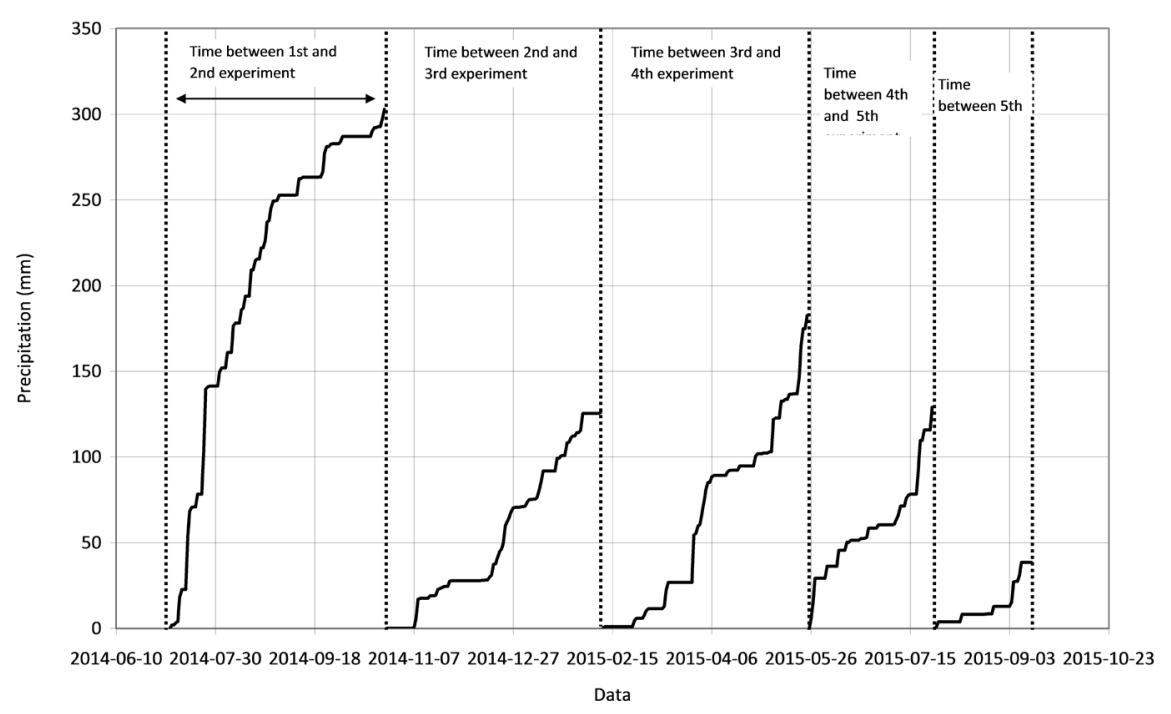

Figure 4. Sum of the daily precipitation between experiments.

driest period. However, the information about the sum of the precipitation is not a sufficient indicator for the determination of soil moisture before the particular experiments. For example, in the case of rainfall-runoff modeling and application of Curve Number method for determination of effective rainfall in a catchment scale (Hejduk et al. 2015) the sum of precipitation of 5 days before the considered rainfall event is an indicator of moisture condition [Banasik et al. 2000].

In the soil science, the 15-day period is applied for example in Lambor (1971) method for characterization of soil moisture. This method is based on daily precipitation and the results, so called anterior precipitation index, can be calculated by following equation:

$$
I_{L}=\left(\frac{1}{120} \cdot \sum_{i=1}^{15} a_{i} \sqrt{P_{i}}\right)^{2}
$$

where: $I_{L}-$ is the index value $\left(\mathrm{I}_{\mathrm{L}}\right.$ varies from 0 to 10 where 10 indicates the full water saturation of soil)

$a_{i}-$ weight depended on the day : weight for a 1 is 15 , weight for a 2 is 14 etc.

$P_{i}-$ precipitation in i -day

The values of $I_{L}$ parameter (Table 2) indicate the moisture condition before the particular experiments. It shows that even if the sum of the rainfall between experiments was high, the 15day period can be very dry. Such situation occurred in the case of experiments conducted on 24.10.2014 and 15.09.2015, when the 15 day period before the experiment was extremely dry. $\mathrm{I}_{\mathrm{L}}$ index differences, comparing to approach shown on Figure 4, should be considered for determination of relation between soil moisture and erosion intensity. It also indicates that the 5-day period, usually used for rainfall-runoff models, can be misleading.

The average temperature of soil varied between plots and time (Table 3). It is generally clear, that during autumn and winter, when the air temperature is lower and energy from the Sun does not add much heat to the soil, the temperature should be lower than during summer time. The variation of temperature between particular plots is connected with land cover. Plot 5, where the forest reduce the sun light intercity, has lower soil temperature in most cases. It is also relevant that the lowest soil temperature during summer were measured at plot 2, which is an open cultivated field. It is possible that wind is an important cooling factor in these cases; however, there was no wind speed research done in this field investigation.

\section{Spatial distribution of erosion and soil moisture within the catchment}

One of the results of rainfall simulator application was the determination of erosion processes intensity differences between particular plots. Application of the same rainfall intensity during the same meteorological conditions allows to compare the concentration of eroded material in runoff from the particular plots. Results of sediment concentration (Fig. 5) at particular plots indicate and confirm the known phenomenon of importance of vegetation cover on erosion process. 
Table 2. Comparison of 5 day sum of precipitation and calculated $\mathrm{I}_{\mathrm{L}}$ parameter.

\begin{tabular}{|c|c|c|c|c|c|c|}
\hline Data & 9.07 .14 & 24.10 .14 & 10.02 .15 & 25.05 .15 & 27.07 .15 & 16.09 .15 \\
\hline $\begin{array}{c}\text { Sum of rainfall from 5 days } \\
\text { before experiment }(\mathrm{mm})\end{array}$ & 0.0 & 10.6 & 0.7 & 45.7 & 19.3 & 0.0 \\
\hline $\mathrm{I}_{\mathrm{L}}$ value & $\mathbf{2 . 6 0 9 5}$ & $\mathbf{0 . 0 0 1 7}$ & $\mathbf{0 . 8 7 9 3}$ & $\mathbf{1 . 0 9 2 4}$ & $\mathbf{1 . 2 8 0 5}$ & $\mathbf{0 . 3 3 1 7}$ \\
\hline
\end{tabular}

Table 3. Average soil temperature during experiments.

\begin{tabular}{|c|c|c|c|c|c|c|}
\hline Plot number & 9.07 .14 & 24.10 .14 & 10.02 .15 & 25.05 .15 & 27.07 .15 & 16.09 .15 \\
\hline 1 & 23.6 & 7.9 & 2.4 & 19.6 & 18.8 & 20.7 \\
\hline 2 & 26.4 & 7.1 & Frozen soil & 15.7 & 19.7 & 20.8 \\
\hline 3 & 28.0 & 9.9 & 3.1 & 17 & 23.8 & 23.2 \\
\hline 4 & 26.7 & 7.7 & 1.6 & 16.4 & 21.0 & 24.9 \\
\hline 5 & 241 & 6.4 & 2.3 & 15.4 & 21.7 & 24.8 \\
\hline
\end{tabular}

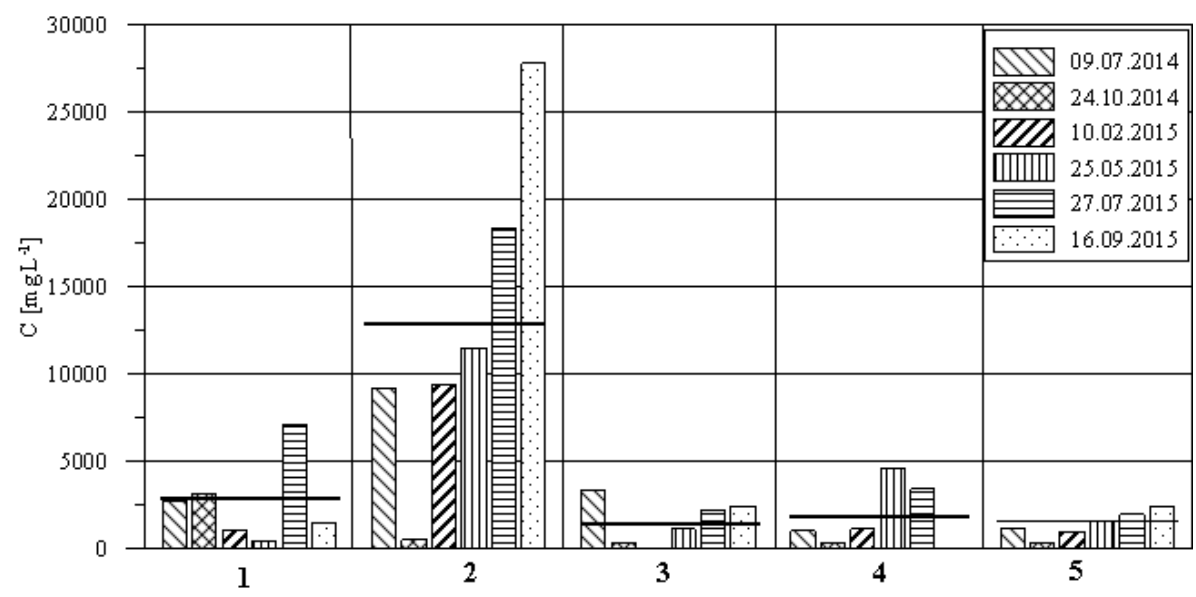

Figure 5. Comparison of sediment concentration in runoff after rainfall simulation for five plots

Plot number 2, the only one with actively cultivated land, significantly generates more sediment, comparing to other plots. The average concentration received from plot 2 was 5 times higher than the one from the plot number 1 with wild meadow as land cover. There were no significant differences between plots under various cultivation and the average sediment concentration varied from $1405 \mathrm{mg} / \mathrm{l}$ at plot number 5 (young forest) to $2658 \mathrm{mg} / \mathrm{l}$ at plot number 1 (wild meadow).

The initial moisture contents (Fig. 6) during the studied period and the relative frequency of SWR (Fig. 7) classes were determined in each of the experiments for the five plots.

As the initial moisture condition is generally more dependent on meteorological situation than other factors, there are no significant differences between particular plots. The plots are generally close to each other and, for example, their soil temperature is similar (Table 2). The initial moisture rather depends on the time of the experiment than on the spatial distribution (Fig. 6). The existence and severity of SWR in the soils measured by WDPT test was found to be closely related to the soil moisture [Hewelke et al. 2016]. The similar pattern can be noticed in the case of SWR classes (Fig. 7), except for the plot number 4 (wild meadow forest succession), where the SWR were almost all the time in class 1 . It can be partially explained by high ground water level (measured long term average of ground water level is $0.66 \mathrm{~m}$ from the ground level) in this point.

\section{Timely distribution of erosion and soil moisture within the catchment}

The metrological conditions varied between particular experiments, which was connected with the fact that they were conducted at different times. In two cases, the experiments were conducted during midsummer, in July 2014 and July 2015, another two were performed during autumn September 2014 and October 2015, one 


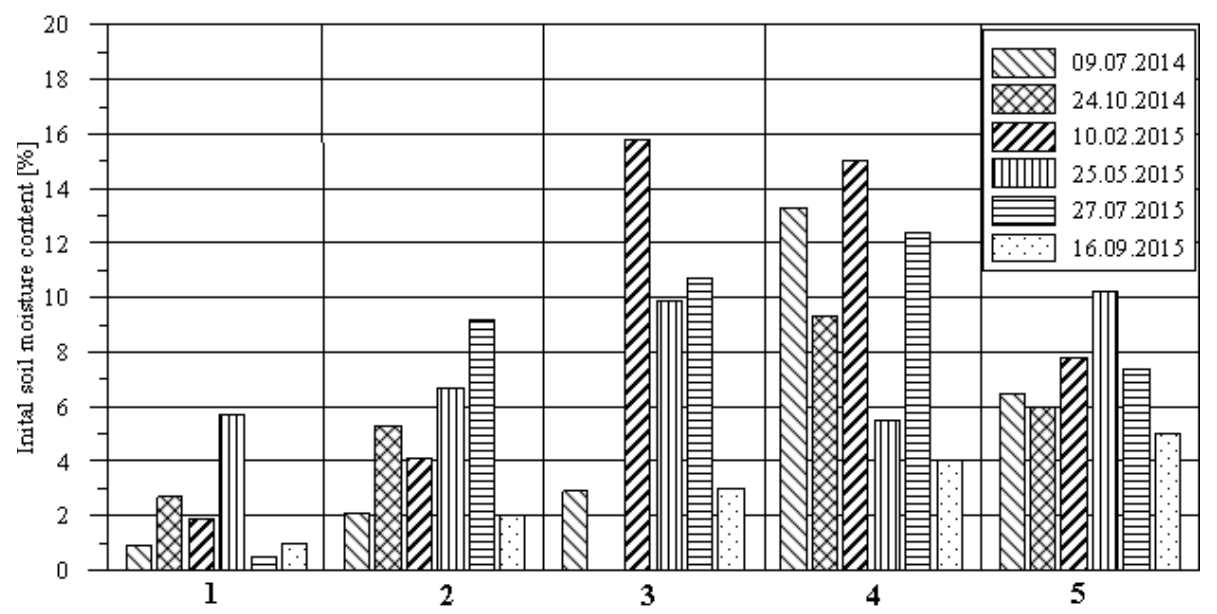

Figure 6. Soil moisture content before particular experiment for five plots

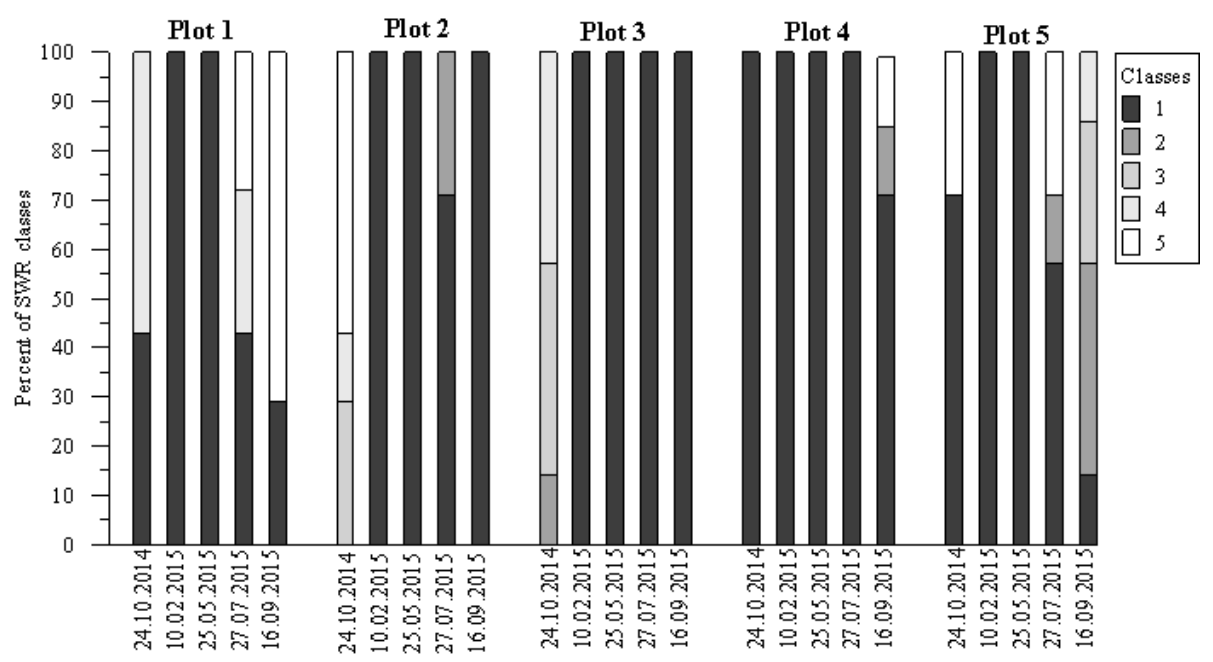

Figure 7. Percentage of SWR classes at particular plots and during 5 experiments (the SWR was not estimated during first experiment)

was conducted during late spring May 2015 and one was carried out during winter February 2014. The significant amount of sediment was always washed out from plot number 2, with agricultural cultivation (Fig. 8). Except for the experiment in October 2014, the concentration of suspended sediment in runoff at this plot were in extreme case, 11 times higher than in the same time at plot number 5 (young forest). This situation should generally be explained by the strong protection of forest against the agricultural land, and general weak protection against erosion by the agricultural cultivation. It is also relevant, that in some experiments the sediment is not received at all. It was connected with the lack of runoff in those cases (experiment 10.02.2014 plot number 3 and experiment 16.09.2015 plot number 4) which means, that all the water used for experiment infiltrated and no runoff was generated.
The soils exhibited markedly seasonal variation for water repellence for all cases (Fig. 7). During October 2014, after the wettest period, only the plot number 4 was wettable, and over $50 \%$ of extremely repellence was observed in plot number 2. All the soils were wettable after the winter months and the repellency increased during the summer, where three of the studied soil sites got repellent. By contrast, the samples collected in late summer exhibited the highest repellency values, as a result of exposure to the dry conditions of summer, i.e. when the soil moisture content was the lowest.

\section{The parameters influencing the erosion processes during experiments}

Among the parameters that strongly influence the erosion processes, the rainfall intensity plays 


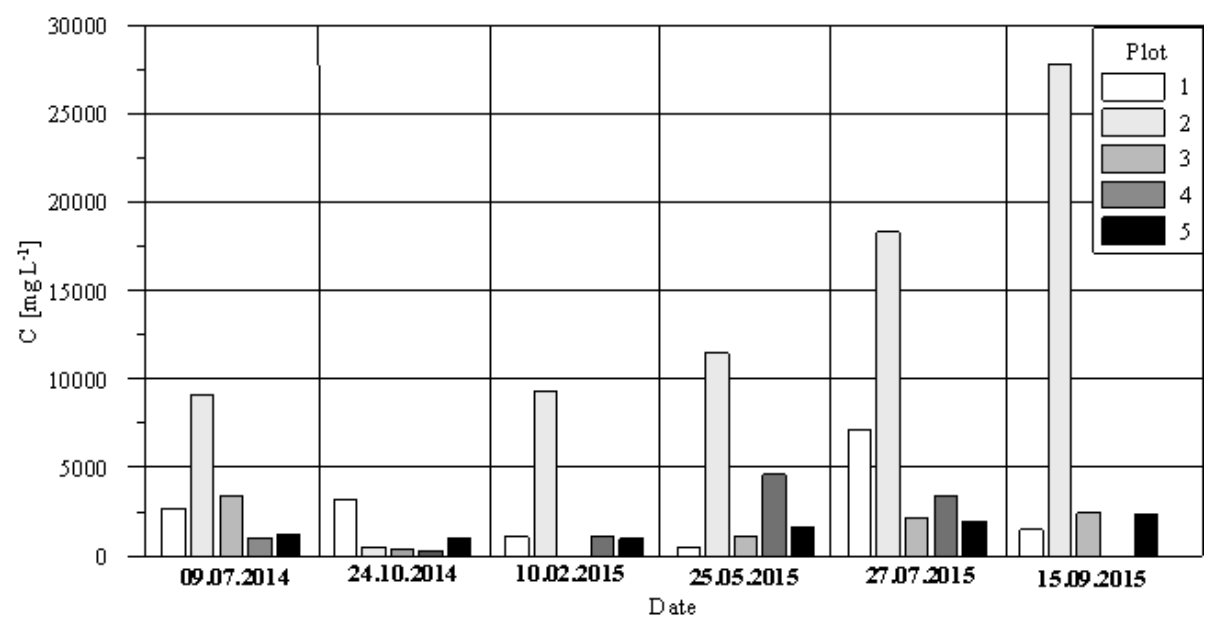

Figure 8. Sediment concentration in runoff during particular experiment.

a significant role. In this experiment, the rainfall intensity has been established as an equal value. Among other parameters, the vegetation cover has also been changing due to natural weather seasonality. When other parameters influencing erosion are assumed as constant (soil types, slope and plot length), it is possible to investigate how various parameters describing soil moisture condition impacted the mass of sediment produced during experiments. Therefore, the relation between sediment mass and following parameters for particular plots was investigated: $I_{L}, 5$ day rainfall, initial moisture condition, soil temperature and runoff volume for all plots, excluding the plot number 2. The removal of plot number 2 data from analysis was caused by significant higher sediment concentration (Fig. 5) received from this plot, connected with agricultural cultivation.

There is a general tendency that sediment mass increases with the amount of water on al-

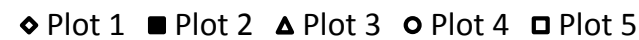

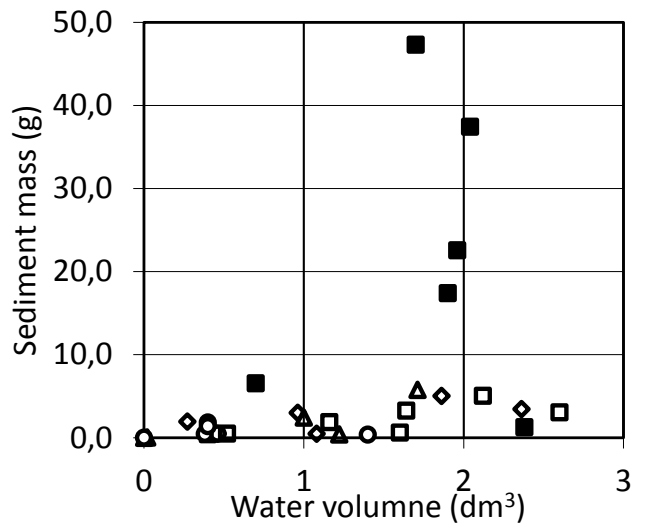

Fig. 9. Relation between sediment mass and water volume measured in the receiving pot (Fig. 3) for all data and plots most all plots (Fig. 9a) except for plot 2 with agricultural cultivation (Fig. 9). Due to limited data, it is not possible to confirm the statistical importance of such relation in this case and the other. It should be understood as preliminary results.

There was no relation between sediment mass and $\mathrm{I}_{\mathrm{L}}$ (Fig. 10 and Fig. 10a) at all plots. The exclusion of data from plot number 2, as it was in case of relation between sediment mass and water volume, does not improve the relation. The relation between sediment mass and sum of rainfall from 5 days suggests the decreasing relationship (Fig. 11a) between those variables. A similar relation has been noticed between sediment mass and initial moisture condition (Fig. 12a), as well as between sediment mass and percentage of SWR class 1 (Fig. 14a). The percentage of SWR class 1 is an indicator of soil wettable before experiment. The higher this percentage, the more wettable the soil. Those results confirm the suggestion pro-

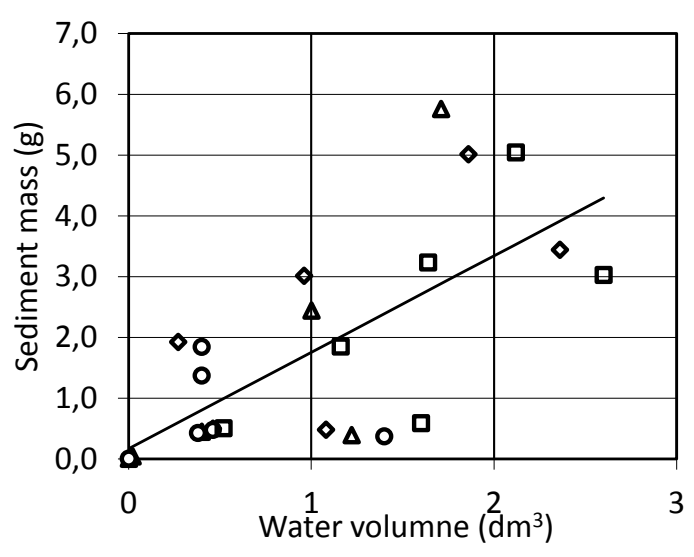

Fig. 9a. Relation between sediment mass and water volume measured in the receiving pot (Fig. 3) for all data without the plot 2 (agricultural cultivation) 
๑Plot 1 - Plot $2 \Delta$ Plot 3 o Plot 4 Plot 5

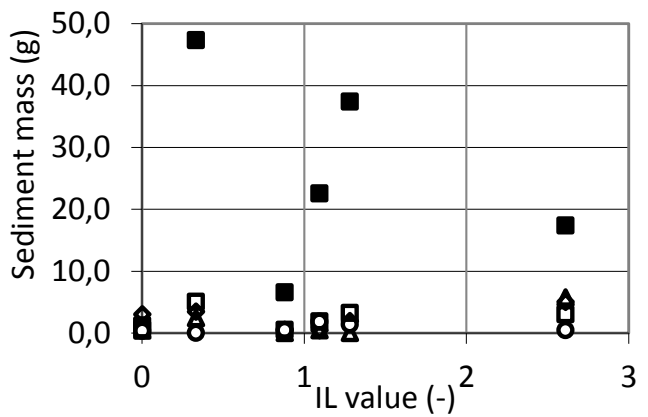

Fig. 10. Relation between sediment mass and $I_{L}$ for all data and plots

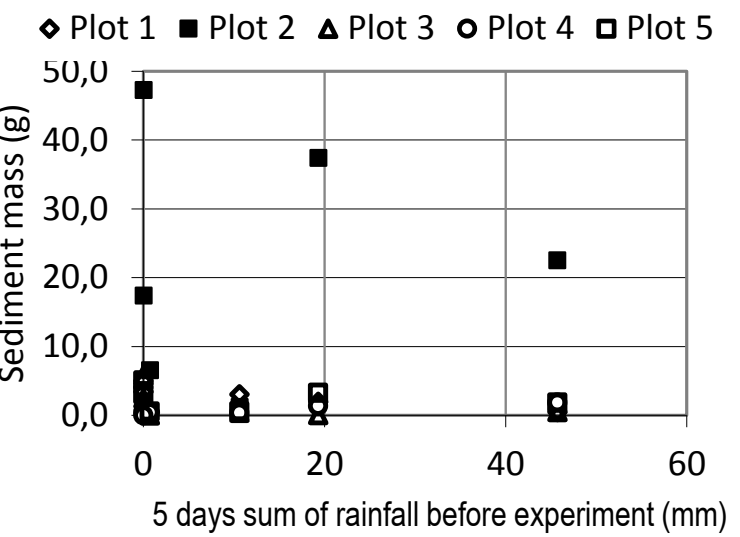

Fig. 11. Relation between sediment mass and sum of rainfall from 5 days before the experiment for all data and plots

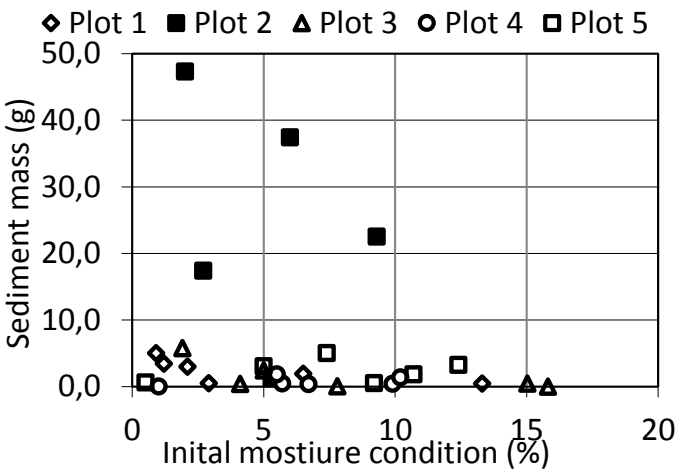

Fig. 12. Relation between sediment mass and initial moisture condition before the experiment for all data and plots

posed by Wei et al. (2007) -for the dry period with deficit of water - that the drier the soil was before the rainfall, the higher soil losses were observed. This may be associated with low values of initial moisture content in most of the terms of measurement (10\%). Only in the period of 25.05.2015, the initial moisture content exceeded 10\%. Dry-
ه Plot $1 \Delta$ Plot 3 o Plot 4 aPlot 5

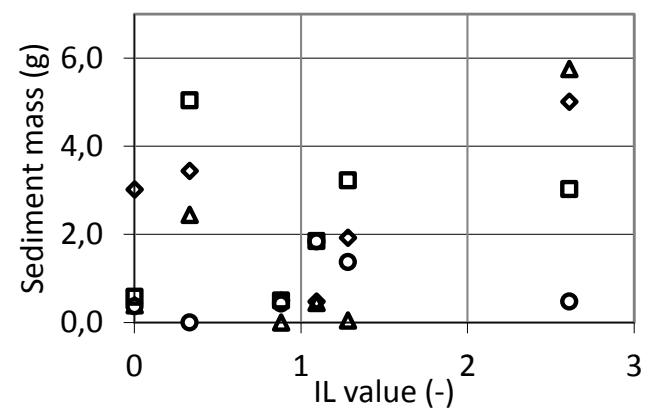

Fig. 10a. Relation between sediment mass and $I_{L}$ for all data excluding the plot 2 (agricultural cultivation)

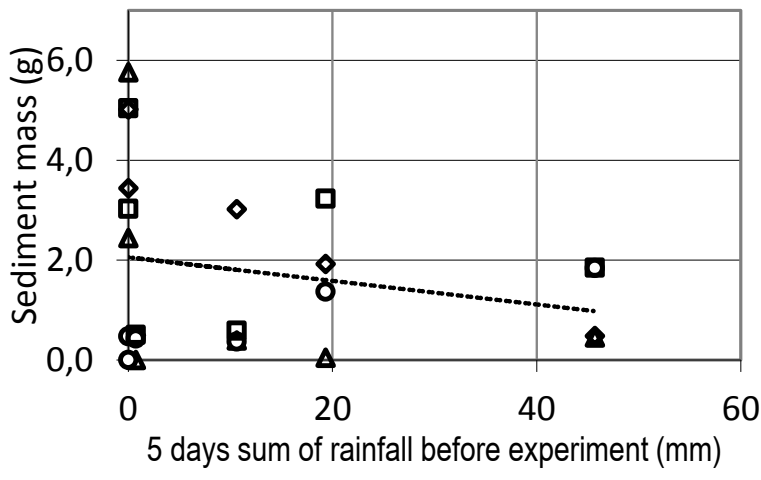

Fig. 11a. Relation between sediment mass and sum of rainfall from 5 days before the experiment for all data excluding the plot 2 (agricultural cultivation)

$\diamond$ Plot $1 \Delta$ Plot 3 o Plot 4 aPlot 5

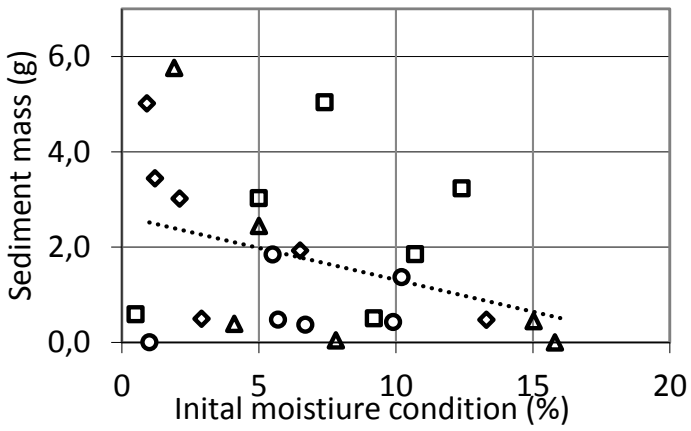

Fig. 12a. Relation between sediment mass and initial moisture condition before the experiment for all data excluding the plot 2 (agricultural cultivation)

ing topsoil, along with other factors such as use, soil compaction, and weather conditions, cause significant differences in the size of surface runoff in the individual dates. The relation between sediment mass and temperature suggests an increase of eroded sediment along with the growing temperature (Fig. 13a). 


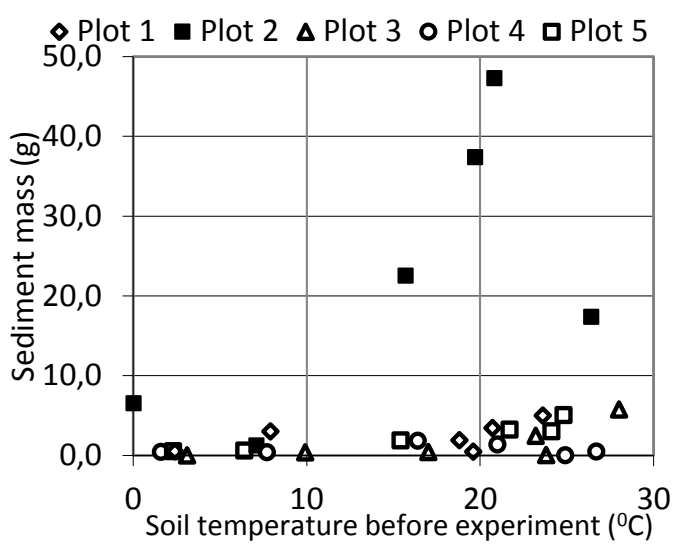

Fig. 13. Relation between sediment mass and soil temperature before the experiment for all data and plots

$\diamond$ Plot $1 \square$ Plot $2 \Delta$ Plot 3 o Plot 4 aPlot 5

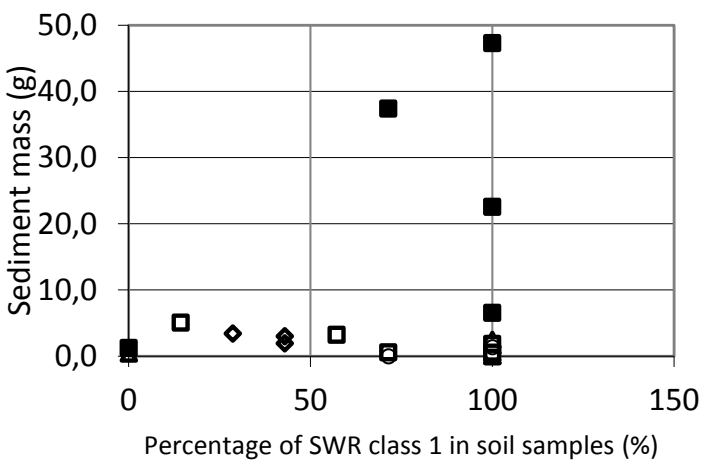

Fig. 14. Relation between sediment mass and percentage of SWR class 1 in soil samples which indicate wettable soil before the experiment for all data and plots

\section{CONCLUSIONS}

The preliminary results of investigation concerning parameters which can have impact on soil erosion at chosen plots in Zagożdżonka river catchment with sandy soils and various cultivation by use of rainfall simulator results in following conclusion:

1. There are significant differences in soil erosion dependent on land cover. The concentration of sediment measured from plot under agricultural cultivation exceeded the sediment concentration measured from other plots with no agricultural cultivation fivefold.

2. The data obtained from experiments allows to search for the relation between the chosen soil moisture indicators and mass of sediment generated during particular experiments. Among the 5 checked relations, the IL parameter seems to be the worst indicator of soil moisture im- $\begin{array}{lllll} & \text { Plot } 1 \quad \Delta & \text { Plot } 3 & \text { o } & \text { Plot } 4\end{array}$

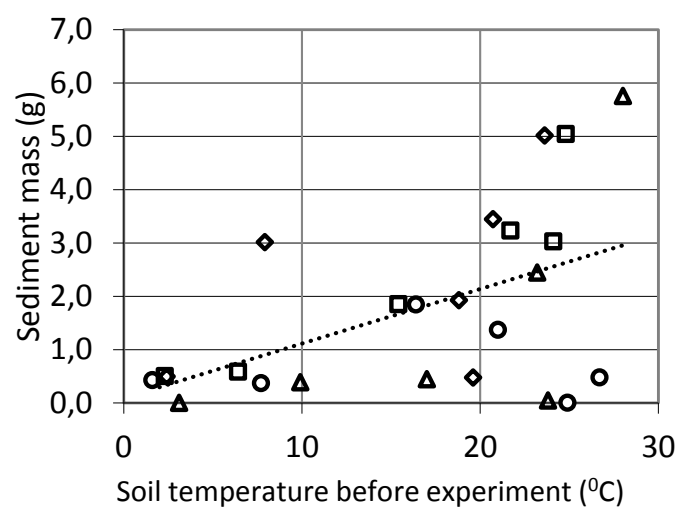

Fig. 13a. Relation between sediment mass and soil temperature before the experiment for all data excluding the plot 2 (agricultural cultivation)

•Plot $1 \Delta$ Plot 3 o Plot 4 aPlot 5

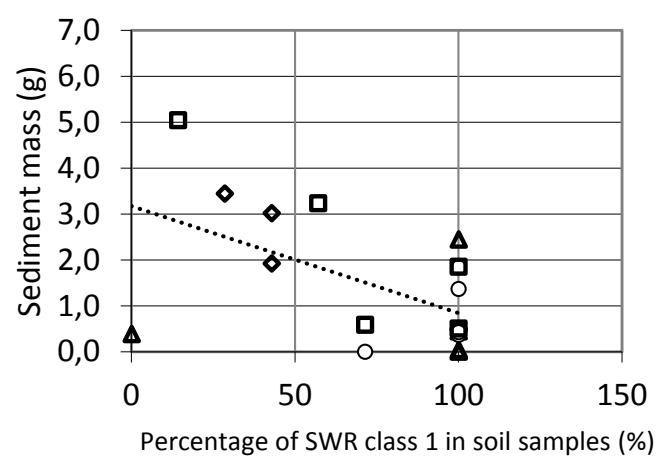

Fig. 14a. Relation between sediment mass and percentage of SWR class 1 in soil samples which indicate wettable soil before the experiment for all data excluding the plot 2 (agricultural cultivation)

pact on mass erosion. This parameter does not show any relation between eroded mass and its values. The decreasing relation between mass of sediment and sum of rainfall from 5 day before experiment, initial moisture condition and SWR class 1 in soil samples were found. However, due to relatively limited data it is not possible to confirm these relations by use of statistical analysis.

3. On the basis of the results from the conducted experiment, it can be concluded that there is a relation between the soil temperature and sediment mass generated during experiment. The mass of sediment grows with the increasing top soil temperature.

4. The tendency of increasing forest area in Zagożdżonka catchment seems to be a straightforward solution for soil protection in the perspective of adopting to the climatic changes. 


\section{Acknowledgements}

Selected data used in this publication were connected with the research project N N305 144540, which was funded by the PL-National Center of Science (NCN)

\section{REFERENCES}

1. Banasik, K. 1994. Sedimentgraph model of rainfall event in a small agricultural watershed, Treaties and Monographs, Warsaw Agricultural University Press, Warsaw, pp. 119 (in Polish).

2. Banasik K.,Górski D., Ignar S. 2000. Modelowanie wezbrań opadowych i jakości odpływu z małych nieobserwowanych zlewni rolniczych. Wyd. SGGW, pp. 74.

3. Banasik K., Hejduk L., Hejduk A., Kaznowska E., Banasik J., Byczkowski A., 2013. Wieloletnia zmienność odpływu z małej zlewni rzecznej w regionie Puszczy Kozienickiej (Long-term variability of runoff from a small catchment in the region of the Kozienice Forest). Sylwan, 157(8), 578-586

4. Banasik, K., Woodward, D.E., Hawkins, R. 2014. Curve Numbers for Two Agro-Forested Watersheds, World Environmental and Water Resources Congress. Water without Borders, ASCE 2014, 2235-2246, 2014b.

5. Bański J., Czapiewski K. 2015. A vision of the polycentric development of the mazovia region in Poland, Geographical Journal 67, 4, 301-321 301.

6. Brodowski R. 2009. Wpływ wilgotności i gęstości gleby lessowej na powierzchniową erozję wodną. Acta Agrophysica, 14(3), 567-576.

7. Cerdà, A. and Doerr, S.H. 2007. Soil wettability, runoff and erodibility of major dry-Mediterranean land use types on calcareous soils. Hydrol. Process., 21:2325-2336. doi:10.1002/hyp.6755

8. Defersha M. B., Quraishi S., and Melesse A. 2011. The effect of slope steepness and antecedent moisture content on interrill erosion, runoff and sediment size distribution in the highlands of Ethiopia, Hydrol. Earth Syst. Sci., 15, 2367-2375, doi:10. 5194/hess-15-2367-2011.

9. Dekker LW, Ritsema CJ. 1994. How water moves in a water repellent sandy soil: 1 . Potential and actual water repellency, Water Resources Research 30: 2507-2517. DOI: 10.1029/94WR00749.

10. Deletic A., 2001. Modeling of water and sediment transport over grassed areas. Journal of Hydrology 248, 168-182.

11. Eijkelkamp 2005. Operating Instructions. 09.06 Rainfall Simulator Eijkelkamp, Maj 2005, pp. 7.

12. Hejduk L., Hejduk A., Banasik K., 2015. Determi- nation of Curve Number for snowmelt-runoff floods in a small catchment. Proc. IAHS, 370, 167-170.

13. Hewelke E., Szatyłowicz J., Gnatowski T., Oleszczuk R., 2016. Effects of soil water repellency on moisture patterns in a degraded Sapric Histosol. Land Degradation \& Development, 27(4), 955-964. DOI: $10.1002 /$ ldr.2305.

14. Iserloh, T., Ries, J.B., Cerdà, A., Echeverría, M.T., Fister, W., Geißler, C., Kuhn, N.J., León, F.J., Peters, P., Schindewolf, M., Schmidt, J., Scholten, T., Seeger, M. 2013. Comparative measurements with seven rainfall simulators on uniform bare fallow land. Zeitschrift für Geomorphologie 57(1), 11-26. DOI:10.1127/0372-8854/2012/S-00085.

15. Lambor J., 1971: Hydrologia inżynierska. Wyd. Arkady, Warszawa.

16. Laflen J.M., Lane L.J., Foster G.R. 1991. WEPP. A new generation of erosion prediction technology. Journal of Soil and Water Conservation, Vol. 46, 34-38.

17. Le Bissonnais Y., Renaux B., Delouche H. 1995. Interactions between soil properties and moisture content in crust formation, runoff and interrill erosion from tilled soils. Catena, 25, 33-46.

18. Misra R.K., Rose C.W. 1996: Application and sensitivity analysis of process-based erosion model GUEST. European Journal of Soil Science, 47, 593-604.

19. Radatz T.F., Thompson A.M. and Madison F.W. 2013.Soil moisture and rainfall intensity thresholds for runoff generation in southwestern Wisconsin agricultural watersheds. Hydrol. Process., 27, 3521-3534. doi: 10.1002/hyp.9460.

20. Ries J.B., Iserloh T., Seeger M., Gabriels D. 2013. Rainfall simulations - constraints, needs and challenges for a future use in soil erosion research. Zeitschrift fur Geomorphologie, Supplementbande, vol. 57, Supplementary Iss. 1, 1-10.

21. Ries, J.B., Seeger, M., Iserloh T., Wistorf, S., Fister W. 2009. Calibration of simulated rainfall characteristics for the study of soil erosion on agricultural land. Soil and Tillage Research 106, 109-116. DOI: 10.1016/j.still.2009.07.005.

22. Rejman J., Usowicz B. 1999: Ilościowy opis przenoszenia gleby i wody w procesie erozji wodnej. Acta Agrofizyka 23, 143-148.

23. Romkens M.J.M., Helming K., Prasad S.N. 2001. Soil erosion under different rainfall intensities, surface roughness, and soil water regimes. Catena, 46, 103-123.

24. Rose, C.W., Williams, J.R., Sander, G.C., Barry, D.A. 1983. A mathematical model for soil erosion and deposition processes: I. Theory for a plane land element. Soil Science Society of America Journal 47, 991-995. 
25. Schmidt J., von Werner M., Michael, A. 1996. EROSION 2D/3D. Ein Computermodell zur Simulation der Bodenerosion durch Wasser, Dresden/ Freiberg.

26. Somorowski C., 1998. Wodno-bilansowe kryteria kształtowania siedlisk w krajobrazie rolniczym. Wyd. SGGW.

27. Starkel L., Kundzewicz Z.B. 2008. Konsekwencje zmian klimatu dla zagospodarowania przestrzennego kraju, NAUKA 1/2008, 85-101.

28. Sulmicka M. 2013. Tendencje rozwoju mazowieckiego rolnictwa. Mazowsze Studia Regionalne 12, 95-106.

29. Wallis MG, Horne DJ. 1992. Soil water repellency. Advances Soil Science 20, 91-146.

30. Wei L., Zhang B., Wang M. 2007. Effects of ante- cedent soil moisture on runoff and soil erosion in alley cropping systems. Agricultural Water Management 94, 54-62.

31. Wischmeier W.H., Smith D.D. 1978. Predicting rainfall erosion losses - a guide to corservation planning. USDA, Handbook No. 537, pp. 58.

32. WRB. 2014. World reference base for soil resources, World Soil Resources Reports 106. FAO, Rome, 2015.

33. Yu B. 2002. Program Notes on Hsview. exe, ROGER.exe and SEADS. exe for hillslope runoff, sediment and nutrients/chemicals generation.

34. Żmuda R, Szewrański S., Sasik J. 2007. Kształtowanie się wilgotności gleby na stoku Wzgórz Trzebnickich. Zeszyty Postepów Nauk Roliniczych, 285-292. 